\title{
Communication
}

[Comunicação]

\section{Squamous cell carcinoma (Bowen's disease) in situ in three cats}

[Carcinoma espinocelular in situ (doença de Bowen) em três gatos]

\author{
L.G. Conceição ${ }^{1}$, L.P. Camargo ${ }^{1}$, P.R.S. Costa ${ }^{1}$, D.A. Kuwabara ${ }^{2}$, C.O. Fonterrada ${ }^{3}$ \\ ${ }^{1}$ Universidade Federal de Viçosa \\ Av. P.H. Rolfs, $\mathrm{s} / \mathrm{n}$ \\ 36571-000 - Viçosa, MG \\ ${ }^{2}$ Clínica Veterinária Pet Fort - São Paulo, SP \\ ${ }^{3}$ Provet - São Paulo, SP
}

In man, Bowen's disease (BD) has been described as a slow-growing disease, characterized by red patches of limited borders, associated or not with hyperkeratosis, crusts, fissures, or pigmentation, and a few millimeters to several centimeters in diameter. Lesions are usually single and affect areas subject to chronic sunlight exposure, especially in old individuals. Men and women are equally affected (Kirkham, 1997; Rinker et al., 2001). In the literature, there are reports of middle-to-old aged cats showing typical lesions of squamous cell carcinoma in situ (SCCS). Although, cats usually show a multicentric lesion, the histopathological findings are similar to $\mathrm{BD}$ described in man (Miller et al., 1992; Gross and Affolter, 1998; Foster et al., 1999; Guaguére et al., 1999). The purpose of this paper is to report BD in three cats referred to a specialized service of small animal dermatology (Provet - SP).

The first case, a 18-year-old male Siamese cat had lesions affecting the left preauricular area for about two years. The cat was treated with several topical and systemic drugs, including antibiotics, corticosteroids and antifungals, and showed no response. During this period, there were improvement and recurred of the lesions, regardless of therapy. Physical examination showed a healthy animal, except for the skin condition. $\mathrm{CBC}$ and urinalysis were within normal ranges; serology for feline immunodeficiency (FIV) and feline leukemia (FeLV), as well as fungal culture, were negative. Dermatological examination showed a hyperkeratotic, hyperchromatic plaque (Fig. 1A) of approximately $1.5 \mathrm{~cm}$ diameter, with fissures and some bleeding. The treatment of choice was surgical excision because of the single nature of the lesion. Histopathology was consistent with SCCS. Eighteen months later, no recurrence of BD was observed. However, the cat had a basal cell tumor on its right ear-margin, but it was healthy.

The second case, a 10-year-old mixed-breed female cat was presented to the service of dermatology with skin lesions in many areas of its body for about one year and a half. Physical examination showed several hyperchromatic, hyperkeratotic, verrucous and crusted plaques (which were ulcerated) on its right preauricular area (Fig. 1B), as well as on its left cervical, abdominal and inguinal areas (Fig. 1C). The cat was otherwise healthy, despite its multiple skin lesions. Skin scrapes for mites and fungal culture were negative. The cat was treated with antibiotics, but it was unsuccessfully. Histopathology of skin lesions was consistent with BD. CBC and chemistry panel (triglycerides, ALT, AP, bilirrubin, BUN, creatinine, albumin, and total serum protein) were within normal ranges and serology for FIV and FeLV were negative. Treatment with oral

Recebido em 27 de junho de 2005

Aceito em 15 de maio de 2007

E-mail: lissandro@ufv.br 
acitretin caused marked lesions improvement for eight months.

The third case, a 10-year-old mixed-breed female cat had skin lesions on its cephalic and cervical areas for one year. Physical examination showed a healthy cat, only with skin lesions. One lesion was a hyperkeratotic and hyperchromatic papule of about $0.5 \mathrm{~cm}$ diameter on the left region of its neck (Fig. 1D). The cat had also two crusted, ulcerated, hyperchromatic papules on its right preauricular and left labial areas, each one of about $0.7 \mathrm{~cm}$ diameter. Histopathology of the neck was consistent with SCCS. CBC and chemistry panel were within normal range; FIV and FeLV serology were negative. The excised lesion did not recur. However, a new lesion developed nearby the excised area. Topical therapy with tretinoin ${ }^{1}$ was prescribed, however, the owner failed to fully comply with the treatment. Currently, the owner chose to watch the lesions without treatment, due to the unchangeable nature of the lesions. Hystopathologic findings of all cats showed similar lesions. Usually, there was an abrupt transition from normal to abnormal epithelium (Fig. 2A). The epidermis showed irregular and psoriasiform hyperplasia, epidermal dysplasia ("windblown" cells) with pleomorphic cells (Fig. 2B), nuclear hyperchromatism, orthokeratosis, loss of cell polarity, ulceration with serocellular crust, and some areas of hyperpigmentation. Dyskeratotic cells were occasionally observed as well. Ballooning degeneration, occasional koilocytosis and hypergranulosis with giant granules were observed (Fig. 2C). Megakariocytic hyperchromatic nuclei with conspicuous nucleolus were also observed (Fig. 2B). Infundibulum of hair follicles frequently showed neoplastic changes similar to those affecting the epidermis (Fig. 2D). At the superficial dermis, there was a slight mononuclear perivascular inflammatory infiltrate, as well as pigmentary incontinence, ectasia and vascular congestion. In case 1, Demodex cati was detected within a hair follicle.

In man, there are many factors predisposing to or associated with BD. In some cases, like in basal cell and squamous cell carcinomas, natural ultraviolet light exposure (Kirkham, 1997; Rinker et al., 2001) or artificial ultraviolet light exposure (UVA therapy) (Takeda et al., 1998) may cause BD. Ingestion and exposure to chemical compounds, such as inorganic arsenic, have been also associated with BD (Kirkham,

${ }^{1}$ Retin $A \circledR$, Cilag.
1997; Rinker et al., 2001). Inorganic arsenic is found in some medicinal herbs, as well as in drugs for treatment of epilepsy, asthma and psoriasis. Up to 1960, inorganic arsenic was a regular ingredient of vitamins and iron compounds. Today, inorganic arsenic is added to several insecticides, fungicides and herbicides (Lee and Wick, 1990).

In the current study, all the three cats had BD lesions in areas of pigmented skin and hair. Because these cats lived in apartments, they practically had no access to outdoors. Therefore, there is neither evidence of actinic injuries, nor history of arsenic exposure. Although the etiology of BD still remains unknown (Foster et al., 1999), it is suggested that ultraviolet light and arsenic exposure are not causal factors in cats (Miller et al., 1992). However, feline BD may represent a malign change of viral papilloma (Gross and Schick, 1992. Power, 2000; Scott et al., 2001).

Histopathologic findings of cases 2 and 3, such as ballooning degeneration, koilocytosis and hypergranulosis also suggest a viral cause, as well as the fact that both cats lived in the same house. Papillomavirus has been domonstrated in some cutaneous lesions by immunohistochemical techniques (Guaguère et al., 1999; Power, 2000; Scott et al., 2001).

One retrospective study reported five cats with Demodex cati infestation; the mites were only within the squamous cell carcinomas. Two hypotheses have been formulated in this respect. The first one states that a local immunodeficiency induced by the tumor could have predisposed the cats to $D$. cati multiplication, like the changes in immunity of man's skin induced by tumors (Guaguère et al., 1999). The second hypothesis associates immunodeficiency with FIV infection, predisposing the cats to papillomavirus-induced carcinoma and Demodex cati infestation. In one study, three cats were FIV positive (Guaguère et al., 1999). All cats in this report were FIV and FeLV negative, and only one (case 1) had Demodex cati infestation at the neoplastic site. These findings support the first hypothesis and, similarly to another study (Miller et al., 1992), FIV and FeLV may not have a significant role in the etiopathogenesis of feline BD. 


\section{Conceição et al.}
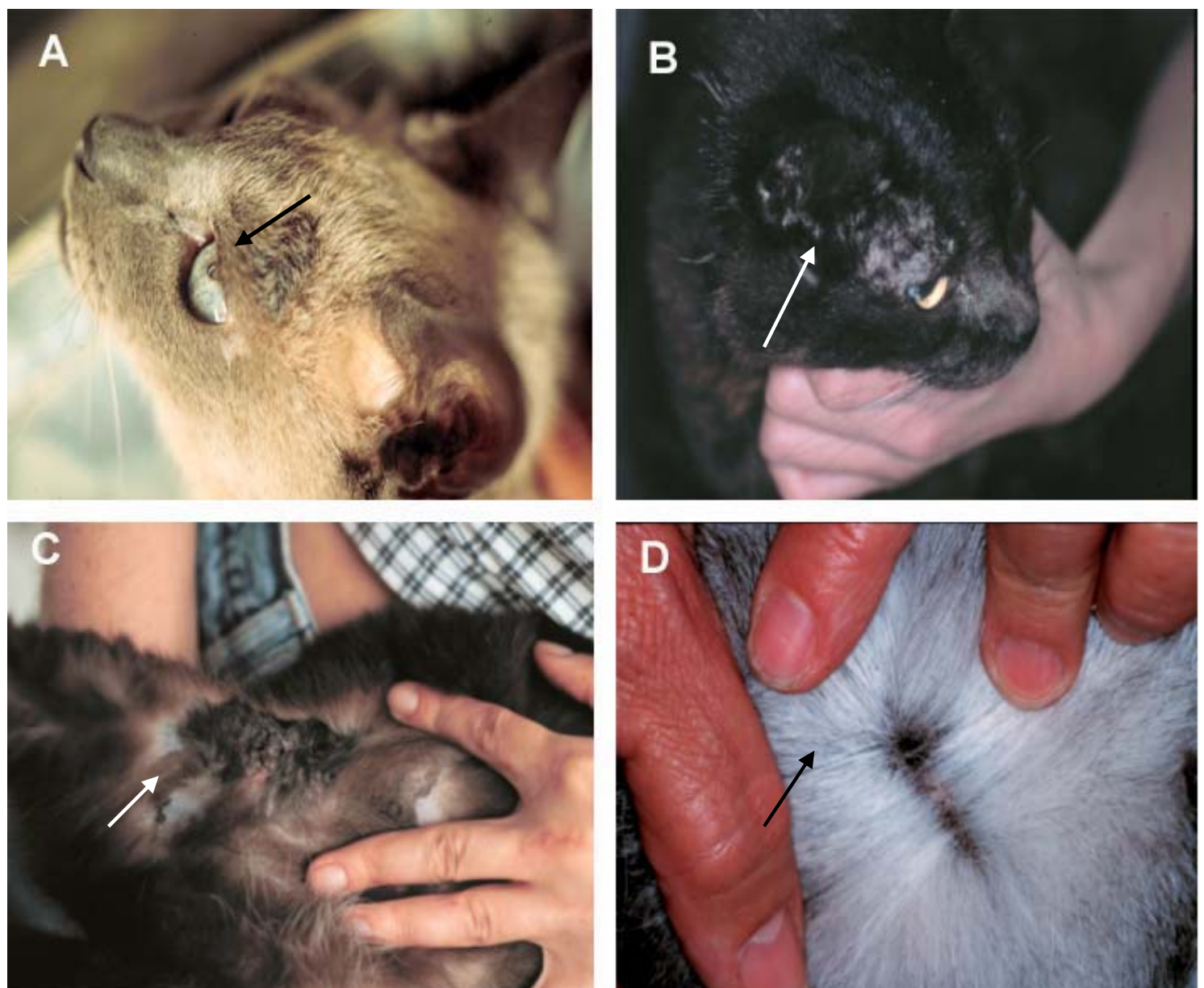

Figure 1. A- Hyperkeratotic and hyperchromatic plaque on the left preauricular area (case1) (arrow). B- Hyperkeratotic and hyperchromatic plaques on the right preauricular area (case 2) (arrow). C- Hyperchromatic, ulcerated, verrucous-crusted plaque on the left inguinal area (case2) (arrow). D- Hyperkeratotic and hyperchromatic papule on the cervical area (case 3) (arrow).

Cat from case 2 developed cutaneous lymphoma 29 months after progression of BD. In cats, there are several reports of other diseases concurrent with BD, including lymphoma (Foster et al., 1999) and thymoma and hepatoma (Rees and Goldschmidt, 1998). Some researchers suggest that an immunosuppression arising from such primary conditions could predispose cats to papillomavirus infection and BD (Gross and Affolter, 1998). In man, an association between BD and other neoplastic conditions is controversial. New findings disagree with previous studies relating $\mathrm{BD}$ to internal malignancies. However, it has been proposed that an indirect association may occur. For instance, arsenic exposure increases the risk for development of BD as well as lung tumors (Lee and Wick, 1990).
BD usually affects middle-to-old-aged animals (Miller et al., 1992; Guaguère et al., 1999; Power, 2000). The mean age of affected patients was 12.6 years. Possibly, there is no breed or gender predisposition to feline BD (Miller et al., 1992; Guaguère et al., 1999; Power, 2000). In cases 1 and 2, lesions had an average course of 21 months before the diagnosis was made. Due to this long and indolent course, two cats were being treated as an inflammatory condition, and as a result several unsuccessful therapies with topical and systemic antibiotics, corticosteroids and antifungal drugs were prescribed. The primary macular lesions, typical of BD (Scott et al., 2001), were not noted by the owners. The cats already had hyperkeratotic, hyperpigmented and crusted plaques, similar to the typical chronic lesions of BD (Miller et al., 1992; Baer and Helton, 1993). 

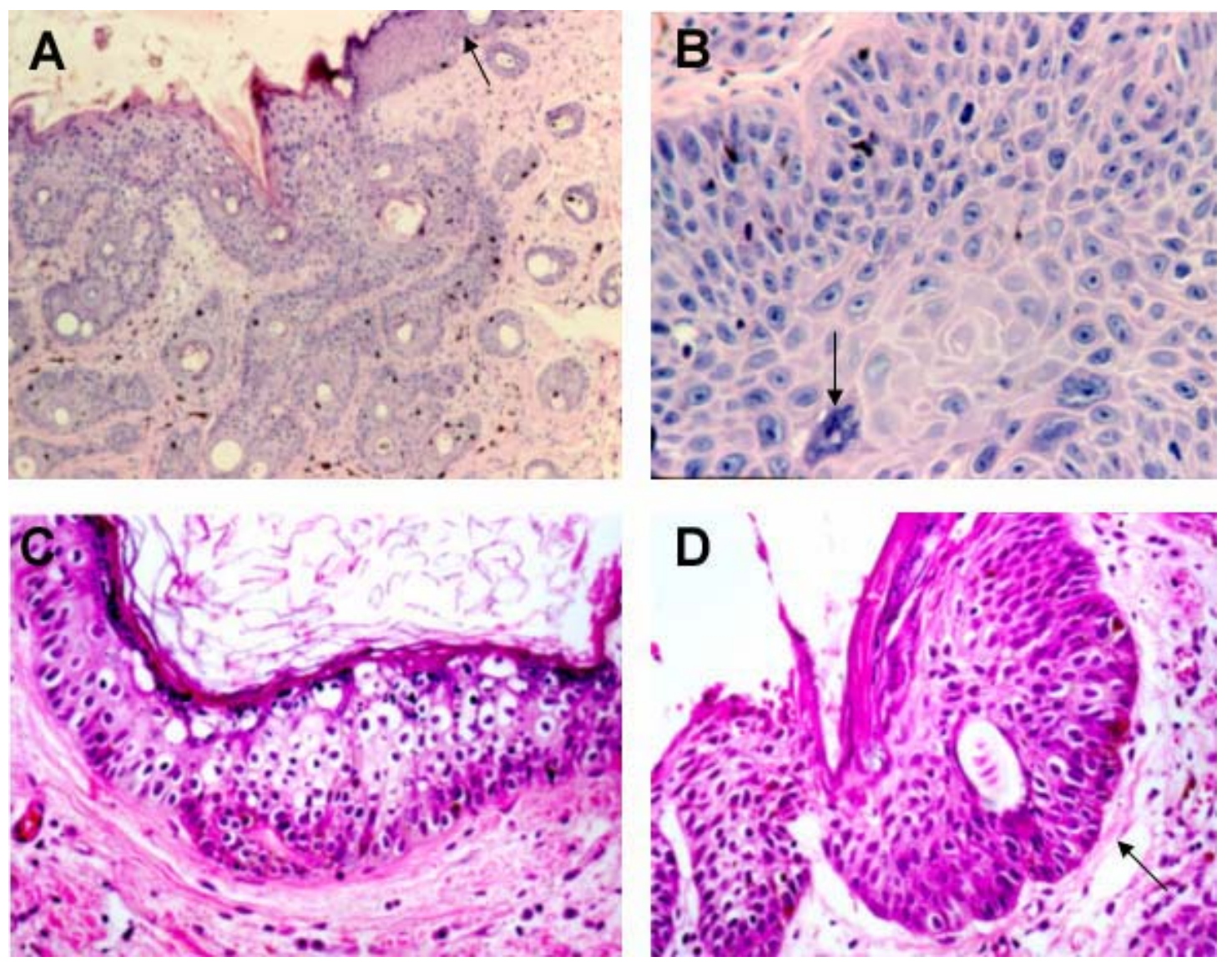

Figure 2. A- Epidermal dysplasia; note the clear limit between normal and dysplastic epidermis (arrow) (HE X 40). B- Megakariocytic cells (cells) (HE X 400) and pleomorphic cell (arrow). C- Ballooning degeneration and epidermal hypergranulosis (HE X 200). D- Dysplastic changes of hair follicle infundibulum (arrow) (HE X 200).

Cutaneous horns, reported in some lesions (Rees and Goldschmidt, 1998), were not found in the cats. Usually, BD lesions in cats are multicentric and affect most frequently the cephalic, cervical and thoracolumbar areas, as well as the forelimbs (Miller et al., 1992; Baer and Helton, 1993). Cases 2 and 3 cats had a multicentric pattern of distribution, but the case 1 cat showed a single lesion on its left preauricular area. There are also reports of single BD lesions in cats, basically limited to the ventral portion of its neck, lateralthorax and medial region of hindlimbs (Baer and Helton, 1993). The major differential diagnosis of $\mathrm{BD}$ in cats is actinic keratosis. Histologically, actinic keratosis may affect the infundibulum of hair follicles (Baer and Helton, 1993), but in a lesser extend than BD. Furthermore, actinic keratosis may show color changes, alternating dark and light epidermal shades. In cats, as well as in man, BD and Bowenoid actinic keratosis are histologically indistinguishable (Baer and Helton, 1993). In man, these diseases are differentiated by size; usually the lesions of actinic keratosis are smaller than the lesions of BD (Kirkham, 1997).

Feline BD affects hairy and pigmented areas, it is not associated with sunlight exposure, and the lesions are multiple in most of the cases. In contrast, the lesions of actinic keratosis are usually single and affect only sunlight-exposed areas, especially in light-colored and hairless skin (Baer and Helton, 1993). However, differentiation of such clinical findings is difficult when BD lesion is single and affects light-colored skin. Although four histological variants of $\mathrm{BD}$ are described in man, only two are described in cats; hyperkeratotic and verrucous and non-hyperkeratotic and irregular (Baer and Helton, 1993). Two cases are 


\section{Conceição et al.}

consistent with the irregular and nonhyperkeratotic type. Maybe "non-hyperkeratotic" is not the most appropriate term, hence the lesions showed different levels of orthokeratosis. Possibly, the other histologic type would be better described as papillomatous-hyperkeratotic, since the word "verrucous" is most appropriate to a gross description of the lesion. A psoriasiform type described in man was noted in one of the lesions found in case 3. In one study, $27 \%$ of feline BD cases showed, histologically, invasive squamous cell carcinoma (Gross and Affolter, 1998). However, none of the patients of this report had this change. Concluding, feline BD should be suspected in any chronic, focal or multifocal, crusted and hyperkeratotic lesions, especially in middle-to-old aged cats not responding to previous treatment.

Keywords: cat, neoplasm, multicentric squamous cell, Bowen's disease, dermatosis

\section{RESUMO}

Três casos de carcinoma multicêntrico in situ de células escamosas (doença de Bowen) são descritos na espécie felina. As neoplasias ocorreram em gatos idosos e acometeram a região pré-auricular, cervical, abdominal e flancos. Um gato apresentou lesão única e os demais apresentaram lesões multifocais, que se caracterizaram por placas que variavam de hiperceratóticas a verruco-crostosas e eram hiperpigmentadas. Algumas eram ulceradas, com fissuras que sangravam facilmente. Histologicamente, as células neoplásicas encontravam-se confinadas à epiderme e aos folículos pilosos, sem o envolvimento da membrana basal. Em um dos casos houve melhora significativa das lesões após terapia oral com acitretina.

Palavras-chave: gato, neoplasia, carcinoma de células escamosas, doença de Bowen, dermatose

\section{REFERENCES}

BAER, K.E.; HELTON, K. Multicentric squamous cell carcinoma in situ resembling Bowen's Disease in cats. Vet. Pathol., v.30, p.535- 543, 1993.

FOSTER, S.F.; CHARLES, J.A.; SWINNEY, G.R. et al. Multiple crusted cutaneous plaques in a cat. Austr. Vet. J., v.77, p.360-368, 1999.

GROSS, T.L.; AFFOLTER, V.K. Advances in skin oncology. In: KWOCHKA, K.W.; WILLEMSE, T.; VON TSCHARNER. C. (Eds.). Advances in veterianry dermatology. Oxford: ButterworthHeinemamm, 1998.v.3, p.383-384.

GROSS, T.L.; SCHICK, R.O. The role of papillomavirus in feline Bowen's disease. In: IHRKE, P.J.; MASON, I.S.; WHITE, S.D. Advances in veterinary dermatology. Oxford: Pergamon,. 1992. v.2, p.417-420.

GUAGUÈRE, E.; OLIVRY, T.; DELVERDIERPOUJADE, A. et al. Demodex cati infestation in association with feline cutaneous squamous cell carcinoma in situ: a report of five cases. Vet. Dermatol., v.10, p.61-67, 1999.

KIRKHAM, N. Tumors and cysts of the epidermis In: LEVER, W.F. (Ed.). Lever's histopathology of the skin. 8.ed. Philadelphia: Lippincott-Raven, 1997. p.685-746.
LEE, M.M.; WICK, M.M. Bowen's disease. Cancer J. Clin., v.40, p.237-243, 1990.

MILLER, W.H.; AFFOLTER, V.; SCOTT, D.W. et al. Multicentric squamous cell carcinomas in situ resembling Bowen's disease in five cats. Vet. Dermatol., v.3, p.177-182, 1992.

POWER, H.T. Update on newly recognized feline skin diseases. In: WORLD CONGRESS OF VETERINARY DERMATOLOGY, 4., Zoon, San Francisco. Procedings... San Francisco: VDP, 2000. p.150-152.

REES, C.A.; GOLDSCHMIDT, M.H. Cutaneous horn and squamous cell carcinoma in situ (Bowen's Disease) in a cat. J. Am. Anim. Hosp. Assoc., v.34, p.485-486, 1998.

RINKER, M.H.; FENSKE, N.A.; GLASS, L.F. Histologic variants of squamous cell carcinoma of the skin. Cancer Control, v.8, p.354-363, 2001.

SCOTT, D.W.; MILLER, W.H.; GRIFFIN C.E. Muller and Kirk's small animal dermatology. 6.ed. Philadelphia: W.B. Saunders, 2001. 1528p.

TAKEDA, H.; MITSUHASHI, Y.; KONDO, S. Multiple squamous cell carcinomas in situ in vitiligo lesions after long-term PUVA therapy. J. Am. Acad. Dermatol., v.38, p.268-270, 1998. 